\title{
Unbound emotional geographies of youth transitions
}

\author{
Kathrin Hörschelmann \\ Leibniz Institute for Regional Geography Leipzig (IfL), Leipzig, Germany \\ Correspondence: Kathrin Hörschelmann (k_hoerschelmann@ifl-leipzig.de)
}

Received: 11 January 2017 - Revised: 18 December 2017 - Accepted: 19 December 2017 - Published: 7 February 2018

\begin{abstract}
This paper makes the case for greater consideration of unbound emotional geographies in research on youth transitions, based on the biographical narratives of young people interviewed as part of a qualitative research project on understandings of (in)security in the German city of Leipzig (2014-2015). The need for more holistic approaches to the complex temporalities and spatialities of transitioning in young people's everyday lives and across their life courses is identified and I propose developing such approaches partly on the basis of less bound understandings of emotion as an important medium through which boundaries are crossed, times and places intersect and both spatial intersections and boundary crossings are sensed and negotiated. The value of such an approach is demonstrated through empirical analysis of the accounts of young people from disadvantaged socioeconomic backgrounds in Leipzig, focusing particularly on interpersonal conflicts and how young people negotiate the resulting emotions in different everyday and institutional contexts. The accounts of research participants in Leipzig show that interpersonal conflicts evoke emotions that reach well beyond localised settings and the present. They also require a significant amount of emotional work to be carried out across a range of everyday informal and institutionalised settings. An approach to emotions as unbound and embodied can help, it is argued here, to better understand how young people negotiate their social positioning across entangled sites and relations and to develop support structures that are more responsive to this entanglement.
\end{abstract}

\section{Introduction}

Research on youth transitions has, over the last two decades, focused primarily on the pluralisation of pathways to adulthood, on the greater uncertainties faced by young people in so-called risk societies and on the double-edged nature of processes of individualisation that entail both choice and compulsion (see Evans, 2008). Critical scholars have paid particular attention to the gap between promises and realities for young people in neoliberal societies, emphasising the persistence and, frequently, worsening of socioeconomic inequalities (Furlong and Cartmel, 1997; Macmillan and Hagan, 2004; Skelton, 2002; Dwyer and Wyn, 2004). Recent calls for greater recognition of young people as beings rather than "becomings" notwithstanding (see Colls and Hörschelmann, 2009; Horton and Kraftl, 2006, 2009), this work mostly focused on young people's trajectories towards the future. There have been few engagements with the spatialities performed in prior, plural transitions and the ways in which seemingly discrete, bound places interconnect through mobilities performed by young people in everyday life and across the life course (see Worth, 2009, 2011, for a critique). As childhood and youth continue to be strongly institutionalised, research has tended to concentrate on specific contexts such as home, school, sites of leisure and consumption or the street (see Holloway et al., 2010; Hopkins, 2013), often treating them as if they exist side by side rather than being interwoven in young people's everyday geographies.

Work on the mobilities of children and youth (Barker et al., 2009; Horton et al., 2014; Nette and Hayden, 2007; Richter et al., 2013) and on education as a sphere for the reproduction and contestation of social differences (see Hanson Thiem, 2009; Holloway et al., 2010; Thomas, 2011) is beginning to fill this gap, drawing attention to interwoven spatialities, performativities, social structures and power relations. I argue in this paper that such work can be usefully complemented by focussing on emotions, not solely as an embodied relation to place (see Davidson et al., 2007; Davidson and Milligan, 2004; Smith et al., 2009), but also as an embodied medium through which time-spaces are brought into con- 
nection and boundaries are transgressed, maintained and/or (re)produced (see Blazek and Windram-Geddes, 2013; Conradson and McKay, 2007). As young people travel across a multitude of interconnected spaces in their everyday lives and across their life courses (see Valentine, 2003; Schier, 2009, 2014; Wood, 2015), their emotional geographies not only relate to specific places, they are also deterritorialised through embodied mobility. Interpersonal conflicts, for example, evoke emotional responses that are rarely contained "within" places. The emotions that they evoke travel with young people and are mediated and moderated by movement as well as across a range of everyday settings. As a medium for sensing and negotiating one's place in the world, they regularly "spill over", breach spatial boundaries, resonate in other places and, in the process, change how the latter are experienced too.

I argue in this paper that literature on youth transitions which overlooks such unbound emotions and the entangled times and spaces that they co-produce risks creating an incomplete picture of young people's life worlds, with implications for the institutional structures that are meant to support them. An approach to emotions as unbound and embodied can help, I propose, to better understand the impacts of interpersonal conflict on young people's senses of self and on how they negotiate their social positioning in and across different everyday settings. Such insights can also help to develop support structures that are more responsive to the differentiated emotional needs of young people, especially those exposed to multiple personal, socioeconomic and educational risks and/or those who are more mobile than planning structures for education and youth work commonly anticipate (see Stadt Leipzig, 2012).

The need for fuller recognition of such unbound emotional geographies of youth transition was brought home to me by the accounts of several participants in the qualitative research project that forms the empirical basis of this paper. The research was conducted with Elisabeth Reich in a youth club in Leipzig (Saxony, Germany) in 2014-2015. It focused on young people's understandings of (in)security (see Hörschelmann and Reich, 2016). A dominant theme in the workshop discussions and biographical interviews conducted were participants' complicated interpersonal relationships, especially with and between parents or other family members. Such conflicts affected many areas of their lives, often over long periods, influencing their education trajectories and future career options, too. Not only did the contradictory emotions evoked by such conflicts carry over into a range of other everyday contexts, where they continued to be worked through by young people and had to be managed in relation to different social expectations and norms (see Hochschild, 1979, 1983; Shields, 2005), they also intersected with emotionally uneven terrains across and within a range of settings, such as schools or the youth club. These settings could be supportive, but for several of our participants school, in particular, added further friction through experiences of bullying or marginalisation.

One example, which gives a first impression of these complex emotional geographies, is that of 17 -year old Maja ${ }^{1}$, who described the consequences of her parents' divorce and of her father's alcoholism as follows:

Maja: "The first thing that happened was that, in fifth grade, my mum and dad separated .... and from then on I went totally downhill, didn't go to school. I was so broken in my head."

Researcher: "Did your dad notice that you weren't well?"

Maja: "He didn't care. He was an alcoholic ... But he was still my dad. I still loved him, even though he was an asshole."

The divorce of her parents set Maja on a complicated, uneven path, where she meandered not only between her parents but also back and forth between giving up school, staying at home and, after several setbacks, investing tremendous efforts into finishing (lower-tier) "main school" (Hauptschule ${ }^{2}$ ) with good grades. This did not protect Maja against further upset, however, as she later had to confront the stigmatisation of main school students as a barrier to entering the labour market (see below).

A focus on the unbound emotional geographies entailed in plural transitions, I suggest in this paper, enables greater recognition of such complicated everyday topographies, drawing our attention further to the interwoven spatialities and temporalities that emerge from the practices of (young) people as sensitive, sense-making, embodied social beings. It builds on conceptualisations of emotions advanced by geographers working with psychoanalytic and/or psychotherapeutic approaches, who understand their dynamism as a function of relational flows (and frictions) between people and between people and places (see Pile, 2010; Bondi, 2005, 2014; Thien, 2011). I argue in this paper for greater attention, however, to emotions as set in motion through bodies that are not fixed in place. Unbound embodied emotions bring places and times into connection in ways that are rarely seamless but that instead often lead to friction, contestation and the demand to "manage" emotions as one transitions between contexts (Gross et al., 2006; Hochschild, 1979, 1983; Shields, 2005).

The paper considers how young people navigate such frictions and the uneven, intersecting topographies of their lives after first reviewing key debates on youth transition, education, emotional geographies and the politics of adjusting emotions across uneven everyday spatialities. While there is, of course, a wide spectrum of emotions that could be considered, the empirical analysis focusses primarily on those

\footnotetext{
${ }^{1}$ All names used in this article are pseudonyms.

${ }^{2}$ Hauptschule is the lowest tier of schools in the Saxon school system.
} 
that arise from interpersonal conflicts in and between the intersecting contexts of family life, education and leisure. The accounts of our research participants in Leipzig show that interpersonal conflicts evoke emotions that reach beyond localised settings and the present. They require a significant amount of emotional work to be carried out across a range of settings. Unsupportive or conflictual institutional climates, or requirements on young people to "manage" their emotions, are shown to place further burdens on young people.

As a discursive analysis cannot access the complex biopsychological processes connoted as "emotions" directly or in an unmediated way (Bondi, 2005, 2014; Pile, 2010), participants' narratives are analysed here mainly for traces or indications of broader and more multi-layered emotional dynamics. The emotional dynamics approximated through this analytic retelling point towards the constant, ongoing need for situated negotiations, retunings and emotional adjustments, which places greater burdens on young people with more complex personal histories of transition and from socially disadvantaged backgrounds (see Blazek and WindramGeddes, 2013; Barker et al., 2009; Hörschelmann and Reich, 2016). How policy interventions such as school well-being programmes and the promotion of social and emotional skills frame and respond to young people's emotional negotiations, and especially to those (expressions of) emotions that "spill over" into institutionalised education spaces from other areas of their lives, is briefly considered in the final discussion. These are compared with the key sources of support identified by participants. Concluding from this argument, I tentatively make some suggestions for the development of public support structures that are more responsive to young people's unbound emotional geographies and their self-defined needs.

\section{Toward unbound emotional geographies of youth transitions}

Critical geographical, sociological and educational scholarship has done much, over the last two decades, to challenge normative understandings of transition as a linear process channelled along predictable pathways with a narrow set of predefined "outcomes" (see Brown et al., 2012; Evans, 2008; Skelton, 2002; Valentine and Skelton, 2007; Valentine, 2003; Worth, 2009, 2011; Wyn et al., 2011; Wyn and Dwyer, 2000; Dwyer and Wyn, 2004). In the area of youth research, these critiques have originated largely from theorisations of risk society (Beck and Beck-Gernsheim, 2002; Giddens, 1991; see Schwiter, 2011; Valentine, 2003), according to which modernity has led to a "decline in certainty about 'traditional' life courses previously sanctioned and structured through institutions such as state schooling and religious and moral norms around sexual relations and family structures" (Evans, 2008:1665). As a consequence, the transition from childhood to adulthood is argued to be "no longer one which is predetermined and mapped out with defined stages and rites of passage", individuals instead being "free to choose their own life path" (Evans, 2008:1665).

A number of critical scholars including Bethan Evans (2008) have, however, challenged the generalised and frequently ahistorical ethnocentric assumptions underpinning such theorisations. They have, by contrast, demonstrated the pernicious persistence of structural inequalities (Wyn and Dwyer, 2000; Dwyer and Wyn, 2004; Furlong and Cartmel, 1997; Katz, 2004; Skelton, 2002) and considered neoliberal subjectivities as normatively tied to processes of biopolitical governance, i.e. through the responsibilisation of individuals and through moral panics about "at-risk" youth and other seemingly unruly social groups that appear to not be able or willing to adopt neoliberal subjectivities (see Kelly, 2001, 2006; Ruddick, 2003; Watson et al., 2012).

Alternative proposals have included arguments for greater attention to the diversity of transitions, the need to foreground young people's diverse voices and agencies, and their continued interdependencies and negotiations of wider social relations, including the family (Wyn et al., 2011; also see Evans, 2008; Mannay, 2015; Richter et al., 2013; Valentine, 2008; Waters, 2003). The "importance of spatiality in young people's transitions across multiple social and cultural contexts" (Evans, 2008:1665), including less spectacular, more mundane, "goings-on", has further been highlighted by a number of geographers (see Horton et al., 2008; Horton and Kraftl, 2006; Kraftl, 2008; Worth, 2009, 2011).

With the exception of Nancy Worth's work on entangled and looped life-course temporalities $(2009,2011)$, there have been few analyses of transition that have asked how young people navigate and rework personal histories in the present through embodied socio-spatial practices. Where the entangled temporalities and spatialities of young people's lives have begun to be recognised, the focus has predominantly been on discourses and social structures as breaching the boundaries of institutionalised and/or discrete spaces (see Catling, 2005; Collins and Coleman, 2008; Cook and Hemming, 2011; Gagen, 2004; Hanson Thiem, 2009; Holloway et al., 2010; Holloway and Valentine, 2003; Holt, 2004, 2007; Thomas, 2011). To what extent institutional boundaries and distances between everyday contexts are breeched through young people's embodied socio-spatial practices and reworkings of their personal histories remains largely unaddressed, however.

Emotional geographies that emphasise relational dynamics and embodied engagements with the world can make a significant contribution here. As Anderson and Smith (2001:10) have argued, they activate a sharper "geographic sensibility", with feelings and emotions being recognised as "key areas of human experience and of our relation to the world" (see Davidson et al., 2007; Smith et al., 2009). Davidson and Milligan (2004:523) similarly note that "[o]ur emotional relations and interactions weave through and help form the fabric of our unique personal geographies". 
Key authors in the burgeoning field of emotional geography mostly agree that emotions are "relationally constituted, dynamic" (Thien, 2011:312; see Smith et al., 2009:6; Blazek and Windram-Geddes, 2013; Bondi, 2005, 2014; Pile, 2010). Despite this, what emerges from several key texts is a persistent focus on locatedness (see Davidson et al., 2007). The dynamism of emotions has mostly been attributed to relations "between individuals, and between individuals and perceptual environments" (Pile, 2010:13; also see Bondi, 2005, 2014). To Davidson and Milligan (2004:524), emotions are thus "understandable - 'sensible' - only in the context of particular places", while Thien (2011) similarly considers emotions as a key aspect of the resonance of place. How emotions, and with them people and places, travel and thus coproduce entangled time-spaces is rarely discussed. As a connective tissue, however, emotions do not just "arise ... in a variety of sociorelational contexts" (Williams, 2001:1). They also, I would argue, spill over, connect and overlap, even as they are constitutive of, and subject to, efforts to displace and disconnect.

In order to understand more fully the motion in emotion and how it contributes to producing entangled, interconnected time-spaces, it is necessary in my view to deliver, as Nast and Pile (2005:4) have put it, body-place relationships "from the fixed coordinates of social relationships and their constitutive spatial registers to places through the body". Emotions are a key aspect of this. They move not just between bodies and between bodies and places but with the bodies through which they flow.

That this embodied movement frequently (co)produces frictional spatialities and temporalities is brought to the fore perhaps most clearly by boundary crossings in everyday life. Such crossings themselves often provoke, and are negotiated through, intense, unbound emotions. Further, it is at the point of crossing into another social space (whether marked by physical/institutional barriers or by sensed changes in social rules) that the durability and intensity of some emotions is often noticed the most and regulated such that they do not "spill over" and are contained. As sociological and social psychological research on emotion management and the politics of emotion has shown (Hochschild, 1979, 1983; Gross et al., 2006; Shields, 2005), emotional boundary crossings are politicised and socially "managed" in ways that frequently tie into efforts to maintain or redraw boundaries, i.e. through prescriptions for the regulation of emotions in specific settings (see Gross et al., 2006). As Shields explains (2005:11), "[t]he many and hurried daily transitions between emotion modes as one moves between personal and family responsibilities and those of work" make it difficult for people to constantly adjust and readjust emotionally in line with sensed or openly expressed social expectations. Where such social expectations are not met, non-fitting emotions become outlawed, while those who seem to embody them "are deemed emotionally inappropriate" and "labelled deviant because they fail to follow or understand social norms as they pertain to emotion" (Shields, 2005:11).

While Shields concentrates on the micropolitics of interpersonal relations, prescriptions for the management of emotions and pathological discourses of inappropriate emotive behaviour circulate widely, not least in the context of education and in debates about "at-risk youth". The micropolitics of emotions thus upscale to underpin, and be in turn affected by, policy interventions such as the promotion of "social and emotional skills" and/or programmes for social and emotional well-being that are based on positive psychology and cognitive-behavioural strategies (Bacete et al., 2014; Green and Norrish, 2013; Watson et al., 2012). I return to this issue after considering how participants in our research navigated complicated landscapes of interpersonal conflict and the emotions evoked by them. The analysis that follows brings to the fore the complicated and frequently intense emotional geographies that arise from conflict. It highlights family relations as a particular area of concern, showing also, however, that recognition of unbound emotions can help to develop more supportive institutional settings.

\section{The porous emotional geographies of youth transitions}

\subsection{Research aims and context}

The conceptual discussion above was prompted by the biographical accounts of young people from socioeconomically disadvantaged backgrounds in Leipzig (Germany), who participated in a pilot research project on young people's experiences and understandings of (in)security in 2014-2015. The research, which I conducted with Elisabeth Reich (see Hörschelmann and Reich, 2016), sought to explore young people's understandings of (in)security in relation to the different scales and spaces through which the latter were sensed, performed and negotiated in their everyday lives. It also aimed to explore connections between personal and socioeconomic desecuritisation on the one hand and young people's engagements with geopolitical security politics on the other hand. For this reason, we took the decision to conduct the research in a youth and social club located in one of Leipzig's most disadvantaged urban areas, the east-southeast social planning area.

The research brought to the fore the complex intertwining of different forms of (in)security in young people's lives (Hörschelmann and Reich, 2016). Due to the time we invested in the project (conducted over 4 months) and the resulting opportunity to build trust and to get to know different facets of participants' lives, we gradually noticed that interpersonal conflicts, and the emotions they evoked, impacted significantly several participants' understandings of self and (in)security. Building on the conceptual discussion above, I pay closer attention to this issue in the following analysis, examining particularly how young people experience, and deal 
emotionally with, different kinds of conflicts across a range of settings in everyday life and over the life course. The analysis highlights family conflict as a particular area of concern and considers obstacles to, as well as opportunities for, educational and youth work institutions to respond sensitively and helpfully to the complex needs that are both indicated by and negotiated through "unbound" emotions.

Education and youth support in Germany have been affected by significant structural changes over the last decade or so, impacting both the need for institutional support and the types of support available to young people. Neoliberal policies of fiscal restraint have led to major reductions in state support for the economically most disadvantaged, affecting families with children and, especially, single-parent households disproportionately (Der Paritätische Gesamtverband, 2017). At the same time, there have been more sustained investment in the provision of daycare facilities for children and an extension of the activities offered by schools, meaning that "all-day schools" (Ganztagsschulen) are increasingly becoming the norm (Deutscher Bundestag, 2017; Reh et al., 2011). At the federal level, new child protection legislation has also led to an extension of school-based social work and to new requirements for the formation of networks between different actors in child and youth support (Deutscher Bundestag, 2017).

Youth support structures have needed to adapt to these changes in numerous ways. Leipzig's municipal Office for Youth, Families and Education, for instance, has recognised the need for increased investment in school social work and targeted support for children and young adults living in poverty and exposed to multiple risks (Stadt Leipzig, 2012). In its overarching plan for children and youth support, it also acknowledges the limitations of youth social work in trying to overcome deeper structural problems. Youth work in the city is organised around seven planning areas that are meant to reflect young people's wider social spaces, each comprising several administrative sub-areas. These planning areas are regularly monitored for the quality and adequacy of provisions in different areas of youth work with the aim of providing both low-threshold, informal social meeting and leisure spaces and more structured socio-cultural and educational programmes, as well as targeted social support (see Stadt Leipzig, 2012). School social work is increasingly offered in Leipzig and has seen an uplift in funding by the state of Saxony recently, with the aim of establishing a social worker at each secondary school (Sächsische Staatskanzlei, 2017).

The city of Leipzig's declared aim is to base its provisions on young people's needs. However, the latter appear to be primarily assessed by statistical indicators, surveys and monitoring reports that rely to a significant extent on the expertise and authority of adult youth workers, managers and researchers, raising questions about the effectiveness of participatory structures and the responsiveness of the city's youth work programmes to young people's self-articulated needs.
While the city manages and funds some of its own programmes and facilities, independent organisations and associations (freie Träger) provide most of the youth work, based on funding bids to the city and other funders. This leads to uncertainty as funding cycles tend to be short. It allows for some flexibility and responsiveness to increased needs, however, and allows a wider range of organisations to provide diversified services.

Our research took place in a social centre and youth club established as an independent association (Verein) of its own. We approached the leading social worker there because the club serves a diverse group of young people (amongst other users) in one of Leipzig's most deprived residential areas (Stadt Leipzig, 2012). Most, though not all, of our participants lived in close proximity to the club, where they met regularly - some spending a good 2 to $3 \mathrm{~h}$ there every evening. We did not conduct a survey of parental occupation, but in the course of the group discussions and biographical interviews it emerged that, in the majority of cases, one parent or both had experienced redundancy at some point and that low-income employment in the service, blue-collar or military sector was the norm. This was reflected in participants' own job aspirations, which were concentrated on the low- to medium-income service sector.

Most of our participants were finishing or had already finished secondary education and were looking for training or work. Between 16 and 20 years of age, they had all grown up in the period following German unification. The political, social and economic upheavals of that time would have thus still affected many of them and their families (see Hörschelmann, 2008; Hörschelmann and Schäfer, 2005). Leipzig saw significant job losses and population decline during this period (Förster, 2004). Although by 2014 this trend had been reversed and population numbers were increasing quickly, the longer-term effects of structural decline combined with reductions in state-welfare support were still felt strongly, reflected in high rates of poverty, precarious employment, unemployment and income inequality. In 2010, Leipzig had the highest levels of relative poverty in Germany, with $27 \%$ of the population living on less than $60 \%$ of mean average incomes (Statistisches Bundesamt, 2010). A child poverty survey conducted by the Bertelsmann Foundation in 2015 meanwhile found that, in the Free State of Saxony, one in four children were growing up in families reliant on welfare support (Hartz IV) (Bertelsmann Stiftung, 2016:5).

\subsection{Research setting and methods}

Our research with young people growing up in these contextual conditions consisted of eight discussion-based group meetings as well as biographical interviews (see Hörschelmann and Reich, 2016). The group meetings were attended by a core group of eight young people (six girls and two boys), while friends of the core participants also joined the discussions from time to time. Seven of the core participants 
and two of the less regular participants (three young men and six young women) took part in the biographical interviews. While our pilot research was small in scale, the time invested allowed deeper insights into different facets of participants' lives and into the complexity of their experiences and understandings than larger-scale research conducted, for instance as group discussions or one-off interviews alone would have done.

The discussions were supplemented by visual exercises and other participatory techniques, such as roleplay, to prompt reflection on issues which may have otherwise been overlooked. This also meant that, on occasion, we had to respond to emotional upset within the group and to resulting changes in dynamics. Thus, we inserted unplanned breaks into the group discussions on some occasions, allowed for silences and for talking through issues that were upsetting participants. We also ensured that we had time to speak with participants individually, after the group discussions, if they wished. It was often at these moments that more nuanced understandings and previously unaddressed experiences of (in)security became noticeable. Participants themselves frequently commented on how we seemed to talk about (in)security even at times when our discussions did not explicitly focus on the issue. As can be seen from this, the research situation itself was in many ways characterised by emotional transitions and transgressions that sensitised us to those that our participants encountered regularly in other parts of their lives. The responses ranged from noisy disruptions and agitated discussions to silence, stops and starts and, on occasion, the temporary withdrawal of participants to another corner of the room we were using, apart from the group but returning to the conversation after taking a break.

Experiences with violence and abuse at home, in public spaces, in school and between peers featured in the accounts of several participants. We did not offer the right context for such experiences to be discussed in depth and with the support that the young people would have needed (see Bondi, 2014), but they nonetheless referred to them frequently and, in the biographical interviews, found space to reflect on them in more detail. At the same time, it was clear that some participants, such as a young woman who was self-harming and another young woman who had been moved into sheltered accommodation, protected themselves against potentially traumatic discussions by keeping references to the most upsetting experiences brief, temporarily adopting more marginal, silent positions in the group or diverting from topics that could have become upsetting for them. We did not feel entitled to probe into these further than participants allowed, though estimating what can and cannot be probed into, in the different research formats, is a tightrope act with few guarantees of being sensitive and understanding enough (also see Bondi, 2013).

\subsection{Interpersonal conflict and the porous emotional geographies of youth transition}

Despite these limits on our ability to talk through some of the most upsetting and hurtful aspect of participants' personal lives, the biographical interviews in particular allowed us to approximate some of the complicated transitions that most of the young people had already experienced and how they negotiated them emotionally within the context of uneven everyday social topographies. These experiences were strongly related to interpersonal conflicts, especially in their families, but also with friends, teachers and other adults in institutional contexts.

Seven of the nine young people who agreed to a biographical interview noted that their parents had separated and/or that relations to one parent or both were fraught. Mostly, the separations and job-related decisions by parents to relocate had meant that these participants had moved home more than once, within the city as well as between regions, and that they had to negotiate whether and when to visit one of their parents or other close family members. The relocations frequently also involved changes of school as well as more or less frequent travel between parents and the need to negotiate relations between them (see Schier, 2009, 2014). For Thomas (16), it involved coping with his changed position in his father's new family while depending on his mother's permission to travel on his own to see his father, who had relocated to a rural region more than $2 \mathrm{~h}$ away from Leipzig:

"Unfortunately, my dad is no longer together with my mum because they used to argue so much. When they went to a party, everything was fine, but as soon as they came home, it all started again, all that shouting, and so now he [father] has a new girlfriend. I hate her. I don't like her at all! ... And now I have heard that they are expecting another baby. Oh shit! I just went into crisis mode. So that's when I decided not to go there anymore ... My dad once suggested, when I was 13 or 12, that I could go to visit him on my own, by train. So we thought about it, but my mother did not want me to go there alone."

Jonathan (17), described similar dependencies and conflicts arising from tense relations between his separated parents that were also, partly, related to disagreements over his and his sister's career and lifestyle choices as well as their ability to make independent decisions, including having their own bank accounts. This even led to the need to take his father to court to revoke his legal guardianship:

Jonathan: "My dad never allows anything. He is still our legal guardian, though. He has to sign everything. I still don't have my own bank account, because he doesn't trust me to look after my own money ... When I said that I wanted to do hairdressing, my mum just said, that's my decision to 
make. In the end, he also had to sign, because the courts said that it's my wish."

Interviewer: "How often do you see your dad?"

Jonathan: "I haven't really seen him for a year now, only at court, but not really ... He says, well, if you want to [see me], you have to come to my place. Well, great! He lives at the other end of town! ... No, I can't, I can't stand him. Since he has started to prohibit everything I want to do, I don't want to anymore. Or I go there and he says: 'Oh, you again!' Not particularly nice, is it?'

Conflicts between parents thus in many ways affected the young people themselves, in terms of the relationships they had with one parent or both, the emotional support they would receive or give and their ability to take independent decisions. In some cases, parental strife and the actions of individual parents also impacted severely on the sense of well-being and personal security of participants. Thus, for Susanne (20), the acrimony between her parents not only affected her in terms of frequent relocations (her parents had separated, then moved back together and later separated again) but was also accompanied by aggressive rows and abuse towards her and her brother. Susanne described her father as dominant and intolerant of both her mother's decision to work and any differences in opinion between him and his children, leading him to become violent towards her brother and creating an atmosphere of fear and oppression at home. She recounted one crucial incident, in which her father hit her brother forcefully in the face. While her brother contested the violence by threatening to report any further incidents to the police, Susanne felt intimidated and frequently withdrew to her room to keep away from arguments and to avoid physical abuse. However, when her mother finally separated from her father and moved with Susanne and her brother into a new flat, problems continued. Susanne described to us that she felt harassed, rather than supported, by her mother, who frequently made derogatory comments about her and, in Susanne's view, severely undermined her self-confidence. Throughout all of this, Susanne nonetheless contributed her income and savings to the family's tight financial budget and, after moving into another city for work, visited them regularly.

While the legally enshrined and age-related dependencies within families restricted significantly the spatial practices and life choices that participants such as Thomas, Jonathan and Susanne could make, they frequently took responsibility for mending and/or maintaining relationships, whether by keeping in touch with parents, siblings and/or other family members or by trying to mediate between conflicting positions. Such efforts to reconcile and mend relationships were often taxing, affecting the young people's senses of self and well-being, while not necessarily being fruitful. Thus, Christiane (18) found that her efforts to make amends with her family were rebuked. Christiane explained that she had been forced to leave home at 16 as a result of arguments that erupted when she sought help for problems related to issues from her childhood that she did not describe to us in any further detail. The rejection from family members despite her desire for, and efforts to achieve, reconciliation intensified her feelings of exclusion. When we met Christiane, she had just left shared shelter accommodation and had moved into a small flat financed through housing support. Following advice by her social worker, she had interrupted her secondary education to complete a course of psychological counselling. Christiane was learning to cope on a limited state welfare allowance (Hartz IV), receiving no financial assistance from her parents. The conflict with them and with her extended family had thus affected most aspects of her life, including her material and psychological well-being and her education.

Problems with family members were not confined to participants' domestic spaces and intra-familial relations, however. They evoked complex emotions that impacted and were negotiated by the young people we spoke with as they transitioned regularly between different everyday spaces, including school. Some of the challenges arising from this were brought home to us by Maja's (17) account, cited in the introduction. Deeply impacted by the need to adjust emotionally to changing situations and needs, Maja interrupted her school education following her father's death and a period of illness. Her everyday geographies also entailed a significant amount of movement between and across sites of conflict, as she actively attempted to mediate between her parents and to redefine her relations with both in a less conflictual way. She described feeling confused, disoriented and frustrated in the process. Psychosomatically, Maja thus responded by sensing the need to "throw up" when she arrived back at her mum's after a weekend with her dad. She stopped taking an interest in school, which led to her having to retake 2 years.

It is not hard to see why Maja struggled with the requirement to "manage" her emotions such that she could transition seamlessly between her two homes and school. Although she described her relationship with her mother as warm and supportive, she seemed to have received staggeringly little support from anybody else, especially within the education system. Indeed, from her perspective, school added to her difficulties, as she was required to take examinations irrespective of two prolonged stays in hospital during her final year. Her individual circumstances were not considered and she failed the examinations, thus leaving school without any qualification or main school certificate. She was then routed onto the wrong course and, only after that, completed main school at a vocational college with a good average of 2.0 (B, second-best possible grade in Germany). This tremendous success, which she had achieved through enormous tenacity and effort, did not protect her against further obstacles, however, this time resulting from the stigmatisation of main school students. A career counsellor from the public job centre told her that she only had limited training and employment options, not be- 
cause of a tight labour market but because "main school students are stupid":

"The reason why I have only just managed to finish main school, which was family related, she didn't get it. So she said: 'Come on, just admit it. You were simply too stupid to finish main school. Anyway, main school is only for stupid kids.' And that's when I lost it. I totally went into her then, in that room."

The offense caused by this career counsellor perhaps unwittingly provoked a momentary overspill of emotions linked to Maja's long history of complex, emotionally upsetting transitions. In a more critical and reflexive context, this could have led to a questioning of the dense web of inequalities that Maja was faced with, but this opportunity was missed along with any chance of offering more tailored support. Likewise, the eruption of emotions that breached the boundaries between different social and personal time-spaces in that instance remained short-lived. While, there and then, Maja responded with anger and spoke her mind, she more or less withdrew to her home after leaving college, telling us that she mainly filled her days by watching television and visiting the youth club. She was looking for vocational training but did not wish to apply for a course that required her to move away from home.

Maja was an exception in this, as most of her friends seemed to accept without question that they would need to relocate for training and work. However, even for them, the requirement to be flexible and mobile came in addition to upheavals they had already experienced. In this, they appeared to have coped with limited formalised support in school or in the social care system, though this was partly counterbalanced by the youth club, as will be shown below. Two participants told us that they saw or had seen a counsellor in school, but in both cases they did not feel that this had been particularly helpful. Sara, who was self-harming, described the counselling as an additional burden, while Marcus thought that he was singled out by the counsellor because of his individualistic appearance and concerns over symbolisms displayed on his clothes that led the counsellor to (mistakenly) assume a neo-Nazi background. In contrast, the problems that Marcus was encountering in school as a result of being bullied by other students and, in his view, even by some teachers, were not picked up.

School also added to Susanne's problems. Rather than being a safe and supportive space, the class she was placed in after moving to Leipzig from a different region became a space of bullying and exclusion, where her mobility marked her out as different:

"I had to listen to stuff like 'Go back to the filthy village [Drecksnest] you've come from. Nobody wants you here!' That's how that started. On the second day of school. They didn't know me! That's when it was all over for me, but that class didn't have a good reputation anyway. Thankfully they were dissolved later, because our main teacher [Klassenlehrer] became ill ... We had a year without a main teacher and then we were divided up across the school ... It got better then, in as far as they left me in peace. But I was still alone. Nobody liked me. But at least they left me in peace."

Susanne sought to contain the difficult emotions provoked by her fellow students' exclusionary boundary enforcements through spatial practices of self-exclusion, non-integration and disconnection. These can be understood as attempts to avoid further hurt and friction by bounding and internalising emotions such as anger, frustration and fear that might otherwise spill over to prompt further hostile responses by her classmates. An unbounding of these emotions, however, could have also offered an opportunity to pick up on the problems that Susanne faced and to develop more helpful responses. Such an opportunity was used by her new main teacher, when she moved classes, and to whom Suzanne was able to forge a more trusting and supportive relationship.

For Susanne, as for many of her friends, such personal relationships were an important anchor through which they experienced care and could develop a stronger sense of selfworth, even if this did not lead to significant changes in the structural conditions of their lives. A similar role was played by friends and social workers at the youth club, which for most of our participants was the main space for socialising. It was not conflict-free. Tensions rose frequently between friends, while the short-term contracts of many staff made it difficult for some young people to build the trusting, reliable relationships they were looking for. Nonetheless, the club emerged as an important "safe space" in which participant could build longer-lasting relationships with peers, test those relationships, receive practical advice from social workers, find a listening ear and express, live and share a wide range of unbound, "overspilling" emotions. Sometimes, they simply seemed to wish to be amongst friends but to be left alone, i.e. to not be further antagonised and to be accepted for how they felt that day. At other times, they vented their anger and frustration vocally. A "safe space" here thus means a responsive rather than a conflict-free space - a space where unbound emotions can be experienced, expressed and tried within the (relatively) safe knowledge that friends and/or adult social workers are able to cope with it and are on hand to help with de-escalating conflicts or to pick up on other support needs. As the space was so highly valued by virtually all of our participants, however, they also worried about the effects of their actions, fearing exclusion from friendships should they overstep a mark and overstretch their friends' patience, i.e. by expressing some of their more intense emotions. This sometimes entailed a tightrope act between (not always clear or unambiguous) needs of individuals to digest and perhaps express different emotions and the balancing of emotions, 
moods and needs between different individuals. As Susanne explained:

"I was so glad to have the club. That I could go there and cry my heart out every day, until all the trouble started again in the evening. ... I still get into those moods sometimes. They are things that have just got burnt into me ... I have days when I get really sad. I don't know why. It just all comes up again and it's just like that, that time comes back up in me and I think, wow, how bad was it for you! I am glad that it's not like that anymore. I think in the end, my friends would have also suffered if I had stayed here [instead of taking up a job in another city]. I am pretty sure of it. Because I just could not control my bad moods anymore in the end. And I just let off steam by having a go at everybody, no matter who stood in front of me ... Just because I felt so much pressure pent up inside me, which I had to release."

The significance of the youth club as a reliable space for working through difficult emotions raises questions about where young people can find such spaces elsewhere in their lives, especially in situations where funding for youth services is limited. Given that school is a fixture in the daily lives of most young people in western societies and that it takes up most of their working days, especially in the case of all-day schools, it is apt to ask whether school can become a similarly responsive "safe" space beyond the primacy of academic learning. This question is being asked increasingly in Anglo-American and Antipodean contexts, partly in response to concerns about violence and bullying in schools and partly due to the perceived need to enhance students' social and emotional skills. The latter has attracted much political support in the US and UK, under the heading of promoting "well-being" in schools (see Andresen, 2014; Bacete et al., 2014; Green and Norrish, 2013; Ungar et al., 2014; Watson et al., 2012). It is increasingly being advocated in German-speaking contexts too (see Becker, 2008; Hascher and Hagenbauer, 2011; Schick and Cierpka, 2003). The schemes that have received most political support, including state-funded programmes in the US and UK, however, have focused mainly on managing students' behaviour and increasing their confidence through completion of exercises developed by positive psychologists and cognitive behavioural therapists (see Brooks et al., 2012; Dweck, 2006; Csikszentmihalyi and Seligman, 2000). While such schemes may contribute to creating more supportive school environments that offer young people with complex personal backgrounds some respite, I have a number of reservations about them. Not only do they appear to place responsibility primarily on young people, focusing on how they "manage" their feelings, they also aim to disentangle young people's interwoven emotional geographies in ways that delegitimise and pathologise certain emotions as well as those who seem to "fail" to contain them. By seeking to contain difficult emotions and teaching students to leave them at the school gate, such schemes run the risk, in my view, of adding further to the burdens that some young people carry, while doing little to support them to work through emotional experiences. Further, if the task of education includes learning about oneself as a holistic human being and about one's place in society, then such containment and individual responsibilisation miss a crucial opportunity to develop, through collective processes, senses of belonging as well as perspectives and coping strategies that engage and work with, rather than expel and pathologise, young people's uneven, emotionally unbound social and personal geographies.

\section{Conclusion}

As this paper has sought to demonstrate, unbound emotional geographies have much to contribute to critical research on (youth) transitions. Instead of propelling young people forever forward into the future and locating them and their "transitions" almost exclusively in segregated spaces, they conceptualise (young) people as beings and becomings with complex personal histories and geographies. By considering embodied emotions as one of the mediums through which places connect, become porous and overlap, we can develop approaches to transition that do greater justice to the diverse embodiments of socio-spatially performed and constructed subjectivities of children and youth. This entails recognising that the emotions evoked, for instance, by interpersonal conflict will often reach beyond localised settings and breach temporal and spatial boundaries as young people sense, rework and seek to cope with them. It also entails recognising that, due to their socially constructed generational positioning, children and young people have fewer options to "manage" and deal with distress through spatial practices such as withdrawal, avoidance or moving away (Parr, 1999; McGrath et al., 2008).

For young people from disadvantaged socioeconomic backgrounds, such as those who took part in our research, a greater focus on unbound emotions means recognising the significant amount of emotional labour and relationship work that they conduct in the course of tackling multiple risks in everyday live and over the life course, in addition to addressing structural injustice. It also means being more attentive to the impacts of family relations and of difficult emotions raised by conflict within families on young people's overall well-being and sense of self. Spatial distancing together with the provision of a responsive social space in the social centre and youth club was particularly helpful, I would argue, for our participants to allow difficult emotions to surface, while knowing that qualified staff were on hand to provide further emotional and practical support. The city of Leipzig itself is taking steps in this direction by extending the provision of school social work and by developing integrated approaches 
to youth support. Its youth plan thus promotes a networked way of working and recognises the need for more tailored provisions. However, this integrated approach is based on an understanding of "social spaces" as urban quarters within which intersecting services and context-specific needs are assessed. There is thus still a gap between young people's diverse experiences of entangled everyday and life-course geographies and the scaling of services as well as the resolution at which they are offered. A system truly tailored to individual needs would, by contrast, invest in creating supportive material spaces and promoting the capacities of those working in key institutions (as well as in the gaps that remain between institutionalised, and home, settings), to recognise and respond more flexibly to the diverse emotional needs of young people, providing both tailored personal support as well as atmospheres of refuge and respite. Thus, daily transitioning periods can be formally included and extended in school programmes and areas can be created for students to take time out for dealing with the emotions that they bring with them. Equipping staff with time and resources to be able to respond through a wide kaleidoscope of interpersonal skills to students would also seem to be a helpful supplement to the extension of formal (school) social support. This requires a shift in public spending priorities, however, at a time when disinvestment in, and the privatisation of, education and leisure is rather the norm and discussions are focused on academic achievement rather than on young people as holistic beings. It also requires challenging the dominance of romantic understandings of family life so that the needs that arise for many young people from personal conflicts in families and from their intersections with structural inequalities receive greater public attention (see Hörschelmann, 2017).

Data availability. The transcripts on which the analysis in this paper is based have not been archived for general use due to the sensitivity of the data and to ensure that participants' anonymity and privacy of their personal information are guaranteed. This is in accordance with formal guarantees given to participants.

Competing interests. The author declares that she has no conflict of interest.

Acknowledgements. I would like to express my sincere gratitude to all of our research participants for sharing their knowledge and experiences with me and Elisabeth Reich. Special thanks also go to the youth workers for their advice and for enabling us to conduct the research in their club. This paper has further benefited substantially from the insightful comments and stimulating ideas of the two special issue editors, for whose support, patience and encouragement I am very thankful.

Edited by: Myriam Houssay-Holzschuch

Reviewed by: two anonymous referees

\section{References}

Anderson, K. and Smith, S. J.: Editorial: emotional geographies, T. I. Brit. Geogr., 26, 7-10, 2001.

Andresen, S.: Educational Science and Child Well-Being, in: Handbook of Child Well-Being, edited by: Ben-Arieh, A., Casas, F., Frones, I., and Korbin, J., Springer Netherlands, 249-278, 2014.

Bacete, F. J. G., Perrin, G. M., Schneider, B. H., and Blanchard, C.: Effects of school on the well-being of children and adolescents, in: Handbook of Child Well-Being, edited by: Ben-Arieh, A., Casas, F., Frones, I., and Korbin, J., Springer Netherlands, 1251-1305, 2014.

Barker, J., Kraftl, P., Horton, J., and Tucker, F.: The road less travelled-new directions in children's and young people's mobility, MOBILITIES-UK, 4, 1-10, 2009.

Beck, U. and Beck-Gernsheim, E.: Individualization: Institutionalized individualism and its social and political consequences, Sage, London, Thousand Oaks and New Delhi, 2002.

Becker, G.: Soziale, moralische und demokratische Kompetenzen fördern. Ein Überblick über schulische Förderkonzepte, Beltz Verlag, Weinheim and Basel, 2008.

Bertelsmann-Stiftung: Factsheet Kinderarmut in Sachsen. Kinder im SGB-II-Bezug, available at: https://www. bertelsmann-stiftung.de//fileadmin/files/Projekte/Familie_ und_Bildung/Factsheet_WB_Kinderarmut_SN_09_2016.pdf (last access: 10 January 2017), 2016.

Blazek, M. and Windram-Geddes, M.: Editorial: thinking and doing children's emotional geographies, Emot. Space Soc., 9, 1-3, 2013.

Bondi, L.: Making connections and thinking through emotions: between geography and psychotherapy, T. I. Brit. Geogr., 30, 433 448, 2005.

Bondi, L.: Research and therapy: generating, meaning and feeling gaps, Qual. Inq., 19, 1-19, 2013.

Bondi, L.: Understanding feelings: Engaging with unconscious communication and embodied knowledge, Emot. Space Soc., 10, 44-54, 2014.

Brooks, R., Brooks, S., and Goldstein, S.: The power of mindsets: Nurturing engagement, motivation, and resilience in students, in: Handbook of research on student engagement, edited by: Christenson, S. L., Reschly, A. L., and Wylie, C., Springer US, 541562, 2012.

Brown, G., Kraftl, P., Pickerill, J., and Upton, C.: Holding the future together: towards a theorisation of the spaces and times of transition, Environ. Plann. A, 44, 1607-1623, 2012.

Catling, S.: Children's personal geographies and the English primary school geography curriculum, Child Geogr., 3, 325-344, 2005.

Collins, D. and Coleman, T.: Social geographies of education: looking within, and beyond, school boundaries, Geogr. Compass, 2, 281-299, 2008.

Colls, R. and Hörschelmann, K.: The geographies of children's and young people's bodied, Child Geogr., 7, 1-6, 2009.

Conradson, D. and McKay, D.: Translocal subjectivities: mobility, connection, emotion, Mobilities-UK, 2, 167-174, 2007.

Cook, V. A. and Hemming, P. J.: Education spaces: embodied dimensions and dynamics, Soc. Cult. Geogr., 12, 1-8, 2011.

Csikszentmihalyi, M. and Seligman, M. E.: Positive psychology: An introduction, Am. Psychol., 55, 5-14, 2000. 
Davidson, J. and Milligan, C.: Embodying emotion sensing space: introducing emotional geographies, Soc. Cult. Geogr., 5, 523532, 2004.

Davidson, J., Smith, M. M., and Bondi, L. (Eds.): Emotional geographies, Ashgate, Aldershot, 2007.

Der Paritätische Gesamtverband: Armutsbericht 2017, Berlin, 2017.

Deutscher Bundestag: Bericht über die Lebenssituation junger Menschen und die Leistungen der Kinderund Jugendhilfe in Deutschland - 15. Kinder- und Jugendbericht - und Stellungnahme der Bundesregierung, Drucksache 18/11050, 2017.

Dweck, C.: Mindset: The new psychology of success, Random House, New York, 2006.

Dwyer, P. and Wyn, J.: Youth, education and risk: facing the future, Routledge, London and New York, 2004.

Evans, B.: Geographies of youth/young people, Geogr. Compass, 2, 1659-1680, 2008.

Förster, P.: Ohne Arbeit keine Freiheit. Warum junge Ostdeutsche rund 15 Jahre nach dem Susammenbruch des Sozialismus noch nicht im gegenwärtigen Kapitalismus angekommen sind, RosaLuxemburg-Stiftung, Leipzig, 2004.

Furlong, A. and Cartmel, F.: Risk and uncertainty in the youth transition, Young, 5, 3-20, 1997.

Gagen, E. A.: Making America flesh: physicality and nationhood in early twentieth-century physical education reform, Cult. Geogr., 11, 417-442, 2004.

Giddens, A.: Modernity and self-identity: Self and society in the late modern age, Stanford University Press, Stanford, 1991.

Green, L. S. and Norrish, J. M.: Enhancing well-being in adolescents: Positive psychology and coaching psychology interventions in schools, in: Research, applications, and interventions for children and adolescents, edited by: Proctor, C. and Linley, P. A., Springer Netherlands, 211-222, 2013.

Gross, J. J., Richards, J. M., and John, O. P.: Emotion regulation in everyday life, in: Emotion regulation in couples and families: Pathways to dysfunction and health, edited by: Snyder, D. K., Simpson, J. A., and Hughes, J. N., APA Press, Washington, 1335, 2006.

Hanson Thiem, C.: Thinking through education: the geographies of contemporary educational restructuring, Prog. Hum. Geog., 33, 154-173, 2009.

Hascher, T. and Hagenauer, G.: Schulisches Wohlbefinden im Jugendalter-Verläufe und Einflussfaktoren, in: Jahrbuch Jugendforschung, edited by: Ittel, A., Merkens, H., and Stecher, L., VS Verlag für Sozialwissenschaften, Springer, Wiesbaden, 15-45, 2011.

Hochschild, A. R.: Emotion work, feeling rules, and social structure, Am. J. Sociol., 551-575, 1979.

Hochschild, A. R.: The managed heart: commercialization of human emotions, University of California Press, Berkeley, 1983.

Holloway, S. L. and Valentine, G.: Cyberkids: children in the information age, Routledge/Falmer, London and New York, 2003.

Holloway, S., Hubbard, P., Jöns, H., and Pimlott-Wilson, H.: Geographies of education and the significance of children, youth and families, Prog. Hum. Geog., 34, 583-600, 2010.

Holt, L.: Children with mind-body differences: performing disability in primary school classrooms, Child Geogr., 2, 219-236, 2004.
Holt, L.: Children's sociospatial (re) production of disability within primary school playgrounds, Environ. Plann. D, 25, 783-802, 2007.

Hopkins, P. E.: Young people, place and identity, Routledge, London and New York, 2013.

Hörschelmann, K.: Transitions to work and the making of neoliberal selves - growing up in (former) East Germany, in: Social justice and neoliberalism: global perspectives, edited by: Smith, A., Alison Stenning, A., and Willis, K., Zed Books, London and New York, 135-163, 2008.

Hörschelmann, K.: Violent geographies of childhood and home: The child in the closet, in: Conflict, Violence and Peace. Geographies of Children and Young People, edited by: Harker, C., Hörschelmann, K., and Skelton, T., Springer, Singapore, 233$251,2017$.

Hörschelmann, K. and Reich, E.: Entangled (in)securities: sketching the scope of geosocial approaches for understanding "webs of (in) security", Geopolitics, 1-18, 2016.

Hörschelmann, K. and Schäfer, N.: Performing the global through the local-globalisation and individualisation in the spatial practices of young East Germans, Child Geogr., 3, 219-242, 2005.

Horton, J. and Kraftl, P.: What else? Some more ways of thinking and doing "children's geographies", Child Geogr., 4, 69-95, 2006.

Horton, J. and Kraftl, P.: What (else) matters? Policy contexts, emotional geographies, Environ. Plann. A, 41, 2984-3002, 2009.

Horton, J., Christensen, P., Kraftl, P., and Hadfield-Hill, S.: "Walking...just walking": how children and young people's everyday pedestrian practices matter, Soc. Cult. Geogr., 15, 94-115, 2004.

Horton, J., Kraftl, P., and Tucker, F.: The challenges of "Children's Geographies": a reaffirmation, Child Geogr. 6, 335-348, 2008.

Horton, J., Christensen, P., Kraftl, P., and Hadfield-Hill, S.: 'Walking, just walking': how children and young people's everyday pedestrian practices matter, Soc. Cult. Geogr., 15, 94-115, 2014.

Katz, C.: Growing up global: economic restructuring and children's everyday lives, University of Minnesota Press, Minneapolis, 2004.

Kelly, P.: Youth at risk: processes of individualisation and responsibilisation in the risk society, Discourse-Abingdon, 22, 23-33, 2001.

Kelly, P.: The entrepreneurial self and "youth at-risk": exploring the horizons of identity in the twenty-first century, J. Youth Stud., 9, 17-32, 2006.

Kraftl, P.: Young people, hope, and childhood-hope, Space Cult., 11, 81-92, 2008.

Macmillan, R. and Hagan, J.: Violence in the transition to adulthood: adolescent victimization, education, and socioeconomic attainment in later life, J. Res. Adolescence, 14, 127-158, 2004.

Mannay, D.: Mother and daughter "homebirds" and possible selves: generational (dis) connections to locality and spatial identity in South Wales, in: Intergenerational Space, edited by: Vanderbeck, R. M. and Worth, N., Routledge Studies in Human Geography, Routledge, London and New York, 100-122, 2015.

McGrath, L., Reavey, P., and Brown, S. D.: The scenes and spaces of anxiety: embodied expressions of distress in public and private fora, Emot. Space Soc., 1, 56-64, 2008.

Nast, H. and Pile, S.: Introduction: MakingPlacesBodies, in: Places through the body, edited by: Nast, H. and Pile, S., Routledge, London and New York, 1-14, 2005. 
Nette, J. and Hayden, M.: Globally mobile children: the sense of belonging, Educ. Stud., 33, 435-444, 2007.

Parr, H.: Mental health and the therapeutic geographies of the city: individual and collective negotiations, in: Therapeutic landscapes: the dynamic between place and wellness, edited by: Williams, A., University Press of America, New York, 50-62, 1999.

Pile, S.: Emotions and affect in recent human geography, T. I. Brit. Geogr., 35, 5-20, 2010.

Reh, S., Rabenstein, K., and Fritzsche, B.: Learning spaces without boundaries? Territories, power and how schools regulate learning, Soc. Cult. Geogr., 12, 83-98, 2011.

Richter, M., Tse, J. K. H., and Waters, J. L.: Transnational youth transitions: becoming adults between Vancouver and Hong Kong, Global Netw., 13, 535-550, 2013.

Ruddick, S.: The politics of aging: Globalization and the restructuring of youth and childhood, Antipode, 35, 334-362, 2003.

Sächsische Staatskanzlei: Schulsozialarbeit braucht Kontinuität und Verlässlichkeit. Neues Landesprogramm Schulsozialarbeit startet in Sachsen, Medienservice Sachsen, 28.02.2017.

Schick, A. and Cierpka, M.: Faustlos: Evaluation eines Curriculums zur Förderung sozial-emotionaler Kompetenzen und zur Gewaltprävention in der Grundschule, Kindh. Entwickl., 12, 100-110, 2003.

Schier, M.: Räumliche Entgrenzung von Arbeit und Familie. Die Herstellung von Familie unter Bedingungen von Multilokalität, Inf. Raumentwickl., 1, 55-66, 2009.

Schier, M.: Multilokalität von Familie in Deutschland, Geogr. Rundsch., 66, 10-14, 2014.

Schwiter, K.: Lebensentwürfe: Junge Erwachsene im Spannungsfeld zwischen Individualität und Geschlechternormen, 47, Campus Verlag, Frankfurt and New York, 2011.

Shields, S. A.: The politics of emotion in everyday life: "appropriate" emotion and claims on identity, Rev. Gen. Psychol., 9, 3-15, 2005.

Skelton, T.: Research on youth transitions: some critical interventions, in: Young people in risk society: the restructuring of youth identities and transitions in late modernity, edited by: Cieslik, M. and Pollock, G., Ashgate, Aldershot, 2002.

Smith, M., Davidson, J., Cameron, L., and Bondi, L.: Geography and Emotion - Emerging Constellations, in: Emotion, place and culture, edited by: Smith, M., Davidson, J., Cameron, L., and Bondi, L., Routledge, London and New York, 1-18, 2009.

Statistisches Bundesamt: Pressemitteilung Nr. 288, 29.08.2013, Armutsgefährdung in Ostdeutschland nach wie vor höher, available at: https://www.destatis.de/DE/PresseService/Presse/ Pressemitteilungen/2013/08/PD13_288_228.html (last access: 10 January 2017), 2010.
Stadt Leipzig: Fachplan Kinder- und Jugendförderung 2012, Leipzig, 2012.

Thien, D.: Emotional life. A companion to social geography, in: A companion to social geography, edited by: Del Casino Jr., V. J., Thomas, M., Cloke, P., and Panelli, R., John Wiley \& Sons, Malden and Oxford, 309-325, 2011.

Thomas, M. E.: Multicultural girlhood: Racism, sexuality, and the conflicted spaces of American education, Temple University Press, Philadelphia, 2011.

Ungar, M., Russell, P., and Connelly, G.: School-based interventions to enhance the resilience of students, J. Educ. Develop. Psychol., 4, 66-83, 2014.

Valentine, G.: Boundary crossings: transitions from childhood to adulthood, Child Geogr., 1, 37-52, 2003.

Valentine, G.: The ties that bind: towards geographies of intimacy, Geogr. Compass, 2, 2097-2110, 2008.

Valentine, G. and Skelton, T.: Re-defining "norms": D/deaf young people's transitions to independence, Sociol. Rev., 55, 104-123, 2007.

Waters, J. L.: "Satellite Kids" in Vancouver, in: Asian migrants and education, edited by: Charney, M. W., Yeoh, B. S. A., and Kiong, T. C., Springer Netherlands, 165-184, 2003.

Watson, D., Emery, C., and Bayliss, P.: Children's social and emotional wellbeing in schools: a critical perspective, Policy Press, Bristol, 2012.

Williams, S.: Emotion and social theory: corporeal reflections on the (ir) rational, Sage, London, Thousand Oaks, New Delhi, 2001.

Wood, B. E.: Border spaces: geographies of youth exclusion, inclusion and liminality, in: Space, landscape and environment. Geographies of children and young people, edited by: Nairn, K., Kraftl, P., and Skelton, T., Springer, Singapore, 1-22, https://doi.org/10.1007/978-981-4585-90-3_21-1, 2015.

Worth, N.: Understanding youth transition as "becoming": identity, time and futurity, Geoforum, 40, 1050-1060, 2009.

Worth, N.: Evaluating life maps as a versatile method for lifecourse geographies, Area, 43, 405-412, 2011.

Wyn, J. and Dwyer, P.: New patterns of youth transition in education, Int. Soc. Sci. J., 52, 147-159, 2000.

Wyn, J., Lantz, S., and Harris, A.: Beyond the "transitions" metaphor: Family relations and young people in late modernity, J. Sociol., 48, 3-22, 2011. 